\title{
Pengaruh Penambahan Abu Ampas Tebu dan Bubur Kertas Koran terhadap Kuat Tekan Beton Mutu K-225
}

\author{
SHANDY PEBRIYANTO, AMIWARTI, SYAHRIL ALZAHRI \\ Program Studi Teknik Sipil, Universitas PGRI, Palembang, Indonesia \\ Email: amiwartiishak@gmail.com
}

\begin{abstract}
ABSTRAK
Tebu merupakan tanaman untuk bahan baku pembuatan gula, dan nira tebu juga dapat kita temui dijual dengan dicampur es atau sering kita kenal dengan es tebu. Permasalahan yang mencuat dari kegiatan tersebut menghasilkan limbah dari perasan tebu yang belum dimanfaatkan secara maksimal. Maka dari itu dilakukan penelitian dilaboratorium dengan mengubah fisik ampas tebu tersebut menjadi abu ampas tebu kemudian dicampurkan ke beton mutu K-225. Tujuan percobaan ini ialah untuk mengetahui perbandingan kuat tekan beton K-225 dengan tambahan abu ampas tebu dan bubur kertas koran dengan kuat tekan beton normal. Metode yang digunakan pada penelitian ini uji coba di laboratorium. Dari hasil uji labor didapatkan hasil bahwa penambahan abu ampas tebu dan bubur kertas koran mengalami penurunan kualitas kuat tekan betonnya. Penambahan kuat tekan beton dengan penambahan abu ampas tebu dan bubur kertas koran hasil yang didapat masing-masing yaitu AAT 5\% + BK 3\% $=K-200$, AAT $5 \%$ $+B K 5 \%=K-175, A A T 5 \%+B K 7 \%=K-137, A A T 5 \%+B K 9 \%=K-113$.
\end{abstract}

Kata kunci: abu, ampas tebu, additive beton

\begin{abstract}
Sugarcane is a plant that is used as raw material for making sugar, and sugar cane juice can also be found sold mixed with ice or often known as sugarcane ice. The problems that arise from these activities produce waste from sugarcane juice in the form of bagasse that has not been utilized optimally. Therefore, a research was carried out in the laboratory by physically changing the bagasse into bagasse ash then mixed into K-225 quality concrete. The method used in this study was a laboratory trial. From the resultssof laboratory tests, it was found that the additions of bagasse ash and newsprint pulp decreased the quality of the compressivesstrength of the concrete. For each addition of the compressives strength of concrete with the additionsof bagasse ash and newsprint pulp, the results obtained are: $A A T 5 \%+B K 3 \%=K-200, A A T 5 \%+B K 5 \%$ $=K-175, A A T 5 \%+B K 7 \%=K-137, A A T 5 \%+B K 9 \%=K-113$.
\end{abstract}

Keywords: ash, bagasse, concrete additive 


\section{PENDAHULUAN}

Beton adalah bagian yang kita jumpai pada proses pembangunan seperti jalan, jembatan, gedung. Kuat tekan beton adalah kemampuan beton keras untuk menahan gaya tekan dalam setiap satu-satuan luas permukaan beton. Sehingga diharapkan agar dapat mengetahui sejauh mana campuran abu ampas tebu pengganti sebagian semen dan bubur kertas koran pengganti sebagian agregat halus (pasir).

\section{METODOLOGI}

\subsection{Pengertian Beton}

Beton dalam konstruksi teknik didefinisikan (dibataskan) sebagai batu buatan yang dicetak pada suatu wadah atau cetakan dalam keadaan cair atau kental, yang kemudian mampu untuk mengeras secara baik. Beton terdiri dari agregat halus, agregat kasar dan suatu bahan pengikat. Bahan pengikat yang lazim dipakai umumnya adalah bahan pengikat yang bersifat hidrolik dalam arti akan mengikat dan mengeras secara baik kalau dicampur dengan air. (Soetjipto, I. dalam Rusyandi, K., Mukodas, J., \& Gunawan, Y. 2012).

Menurut Rohman dan Cahyono dalam Rajagukguk, S. A. 2017, beton merupakan bahan yang paling banyak digunakan sebagai bahan konstruksi bangunan. Beton didefinisikan sebagai campuran semen portland atau semen hidraulik yang lain, agregat kasar, agregat halus dan air, dengan atau tanpa bahan tambahan berbentuk masa padat.

Menurut Mulyono dalam Adiguna, A., \& Wahyudi, A. 2020, beton merupakan fungsi dari bahan penyusunnya yang terdiri dari bahan semen hidrolis (Portland cement), agregat kasar, agregat halus, air dan dengan menggunakan atau tidak menggunakan bahan tambahan (admixture atau additive) atau campuran semen Portland atau semen hidraulik yang lain, agregat kasar, agregat halus, air dan air dengan atau tanpa bahan tambahan yang membentuk masa padat.

Beton terdiri dari agregat semen dan air yang dicampur bersama dalam keadaan plastis dan mudah dikerjakan. Karena sifat-sifat tersebut, beton mudah dibentuk sesuai keinginan pengguna. Segera setelah pencampuran, campuran terjadi reaksi kimia yang umumnya menghidrasi dan menghasilkan pengerasan dan peningkatan kekuatan. (Ahmad, I. A. \& Taufieq, N. A. S. dalam Pertiwi, N., 2017)

\subsection{Material Pembentuk Beton}

\subsubsection{Semen}

Semen berasal dari kata caementum (Latin) yang berarti memotong menjadi bagianbagian kecil yang tidak beraturan. Sedangkan dalam pengertian semen adalah suatu zat yang digunakan untuk merekatkan batako, batu bata dan bahan bangunan lainnya. Menurut Kamus Besar Bahasa Indonesia (KBBI), semen adalah bubuk atau tepung yang terbuat dari kapur dan bahan lain yang digunakan untuk membuat beton, merekatkan batu bata atau dinding (Riski, A., \& Farlin, R., 2019).

Menurut Hidayat, S. (2009), semen adalah bahan untuk kerikil, pasir, batu bata, dan jenis bahan lainnya. Begitu pentingnya semen, tidak ada bangunan yang lepas dari penggunaan semen. Bahkan semen sudah digunakan sejak zaman dahulu, terbukti dengan banyaknya bangunan bersejarah yang masih bisa kita lihat hingga saat ini. Awalnya, semen dibentuk dengan menggiling beberapa bahan, seperti batu kapur, tanah liat, pasir silika, pasir besi, hingga membentuk klinker. Ditambah beberapa gipsum dan lainnya, maka terbentuklah semen. Semen dapat berfungsi sebagai perekat bila ditambahkan dengan air. 
Semen adalah senyawa atau zat pengikat hidrolis yang terdiri dari senyawa C-S-H (kalsium silikat hidrat) yang bila direaksikan dengan air akan mengikat bahan padat lainnya membentuk suatu kesatuan yang kompak padat dan keras. Fungsi semen adalah untuk mengisi rongga-rongga di antara butir-butir agregat sehingga terjadi massa yang kompak atau padat. (Gardjito, E., Candra, I, A. \& Cahyo, Y., 2013).

\subsubsection{Agregat}

Agregat kasar adalah agregat yang ukuran butirnya lebih besar dari 114,801 mm. Agregat kasar juga dikenal sebagai kericak, kerikil, split, atau batu pecah. Persyaratan agregat halus yang baik untuk digunakan sebagai bahan campuran beton antara lain sebagai berikut:

1. Kekekalan jika diuji dengan natrium sulfat bagian yang hancur maksimum $10 \%$ dan jika dipakai magnesium sulfat bagian yang hancur maksimum $15 \%$.

2. Agregat halus tidak boleh reaktif terhadap alkali.

3. Agregat halus memiliki modulus butir halus antara $1,50-3,80$.

4. Agregat halus tidak terlalu banyak mengandung bahan organik, terbukti dengan percobaan warna dengan larutan $\mathrm{NaOH} 3 \%$ yaitu warna cairan di atas endapan tidak boleh lebih gelap dari warna standar atau perbandingan.

5. Agregat halus tidak boleh mengandung lumpur lebih dari $5 \%$.

Persyaratan agregat kasar yang baik untuk bahan campuran beton adalah sebagai berikut:

1. Agregat kasar memiliki daya tahan maksimum $12 \%$ dari bagian yang hancur saat diuji.

2. Agregat kasar tidak boleh mengandung zat-zat yang reaktif terhadap alkali.

3. Agregat kasar tidak mengandung butiran yang panjang dan pipih lebih dari $20 \%$.

4. Agregat kasar tidak mengandung butiran yang pipih dan panjang lebih dari $20 \%$. Agregat kasar mempunyai ukuran butir maksimum tidak lebih dari 1/5 jarak terkecil antara bidang samping cetakan, 1/3 tebal pelat beton, jarak bersih antar tulangan atau balok tulangan.

5. Agregat kasar tidak boleh mengandung kadar lumpur yang maksimum dengan natrium sulfat dan jika diuji dengan magnesium sulfat bagian yang dihancurkan maksimum adalah $18 \%$.

\subsubsection{Air}

Menurut Kodoatie dan Sjarief dalam Yulianti, A. (2015), air adalah suatu zat cair yang tidak mempunyai rasa, bau dan warna serta terdiri dari hidrogen dan oksigen dengan rumus kimia $\mathrm{H}_{2} \mathrm{O}$. Karena air mempunyai sifat yang hampir bisa digunakan untuk apa saja, maka air merupakan zat yang paling penting bagi semua bentuk kehidupan (tumbuhan, hewan, dan manusia) sampai saat ini selain matahari yang merupakan sumber energi. Air dapat berupa air tawar dan air asin (air laut) yang merupakan bagian terbesar di bumi ini. Di dalam lingkungan alam proses, perubahan wujud, gerakan aliran air (di permukaaan tanah, di dalam tanah, dan di udara) dan jenis air mengikuti suatu siklus keseimbangan dan dikenal dengan istilah siklus hidrologi.

Air adalah salah satu bahan penyusun yang berguna untuk bereaksi dengan semen portland agar berbentuk pasta untuk mengikat agregat. Menurut standar bahan bangunan bagian A (SK SNI 03-2847-2002). Air yang dapat digunakan dalam proses pencampuran beton adalah sebagai berikut:

1. Air yang digunakan dalam campuran beton harus bersih dan bebas dari kotoran, zat merusak yang mengandung minyak, asam, alkali, garam, bahan organik, atau bahan lain yang merusak beton atau tulangan. 
2. Pencampuran air yang digunakan pada beton prategang atau dalam di dalamnya tertanam logam aluminium, termasuk air gratis yang terkandung dalam agregat, tidak boleh mengandung ion klorida dalam jumlah besar membahayakan.

3. Air yang tidak dapat diminum tidak boleh digunakan pada beton, kecuali, kondisi berikut terpenuhi:

a. Pemilihan proporsi campuran beton harus didasarkan pada campuran beton menggunakan air dari sumber yang sama.

b. Hasil pengujian pada umur 7 dan 28 hari pada mortar kubus uji adalah terbuat dari campuran dengan air yang tidak dapat diminum harus memiliki kekuatan setidaknya sama dengan $90 \%$ dari kekuatan benda uji dibuat dengan air minum. Perbandingan uji kekuatan harus dilakukan pada campuran yang sama, kecuali air pencampur, yang diuji sesuai dengan "Metode uji kuat tekan untuk mortar semen hidrolik menggunakan benda uji kubus dengan ukuran sisi 50 mm" ASTM C 109.

\subsection{Abu Ampas Tebu}

Ampas tebu merupakan residu dari proses penggilingan tebu (Saccharum oficinarum) setelah diekstraksi atau dilepaskan di industri pemurnian gula sehingga diperoleh produk limbah berserat dalam jumlah besar yang dikenal sebagai ampas tebu (bagasse). Dalam proses penggilingan tebu, ada lima kali proses penggilingan dari tebu menjadi ampas tebu. Ampas tebu (sugarcane baggase ash) untuk mengurangi sampah karena alasan ekonomi, lingkungan dan teknis. Abu ampas tebu terutama berisi ion aluminium dan silika. Abu ampas tebu telah dikarakterisasi secara kimia dan fisik dan substitusi parsial dengan rasio $0 \%, 5 \%, 15 \%$ dan $25 \%$ dari berat semen dalam beton (Tamilnadu, P. A. dalam Katrina, G., 2014).

\subsection{Bubur Kertas Koran}

Koran adalah sebuah media massa yang dicetak dan disusun atau dibentuk dari kertas buram yang berukuran besar yang isinya memuat tentang informasi-informasi seputar kehidupan sehari-hari dan informasi sekitar. Setiap hari informasi yang disajikan bervariasi, dari itu banyaknya tumpukan limbah kertas koran yang telah dibaca dapat dimanfaatkan sebagai pengganti sebagian agregat halus (pasir) pada campuran beton.

\subsection{Kuat Tekan Beton}

Kuat tekan beton adalah besarnya beban per satuan luas yang menyebabkan benda uji beton hancur bila dibebani dengan gaya tekan tertentu, yang dihasilkan oleh mesin press (SNI 031974-1990). Kuat tekan beton menentukan kualitas suatu struktur. Semakin tinggi kekuatan struktur yang diinginkan, maka semakin tinggi pula mutu beton yang dihasilkan. Nilai kuat tekan beton diperoleh dari pengujian standar dengan benda uji yang biasa digunakan berupa silinder. Dimensi spesimen standar adalah tinggi $300 \mathrm{~mm}$ dan diameter $150 \mathrm{~mm}$. Prosedur pengujian yang umum digunakan adalah standar ASTM C3986. Kuat tekan masing-masing benda uji ditentukan oleh tegangan tekan tertinggi $\left(f_{c}^{\prime}\right)$ yang dicapai oleh umur benda uji 28 hari akibat beban selama percobaan (Mulyono dalam Permatasari, S., 2009).

\section{ANALISIS DATA}

\subsection{Bagan Alir}

Bagan alir penelitian terlihat pada Gambar 1 berikut. 


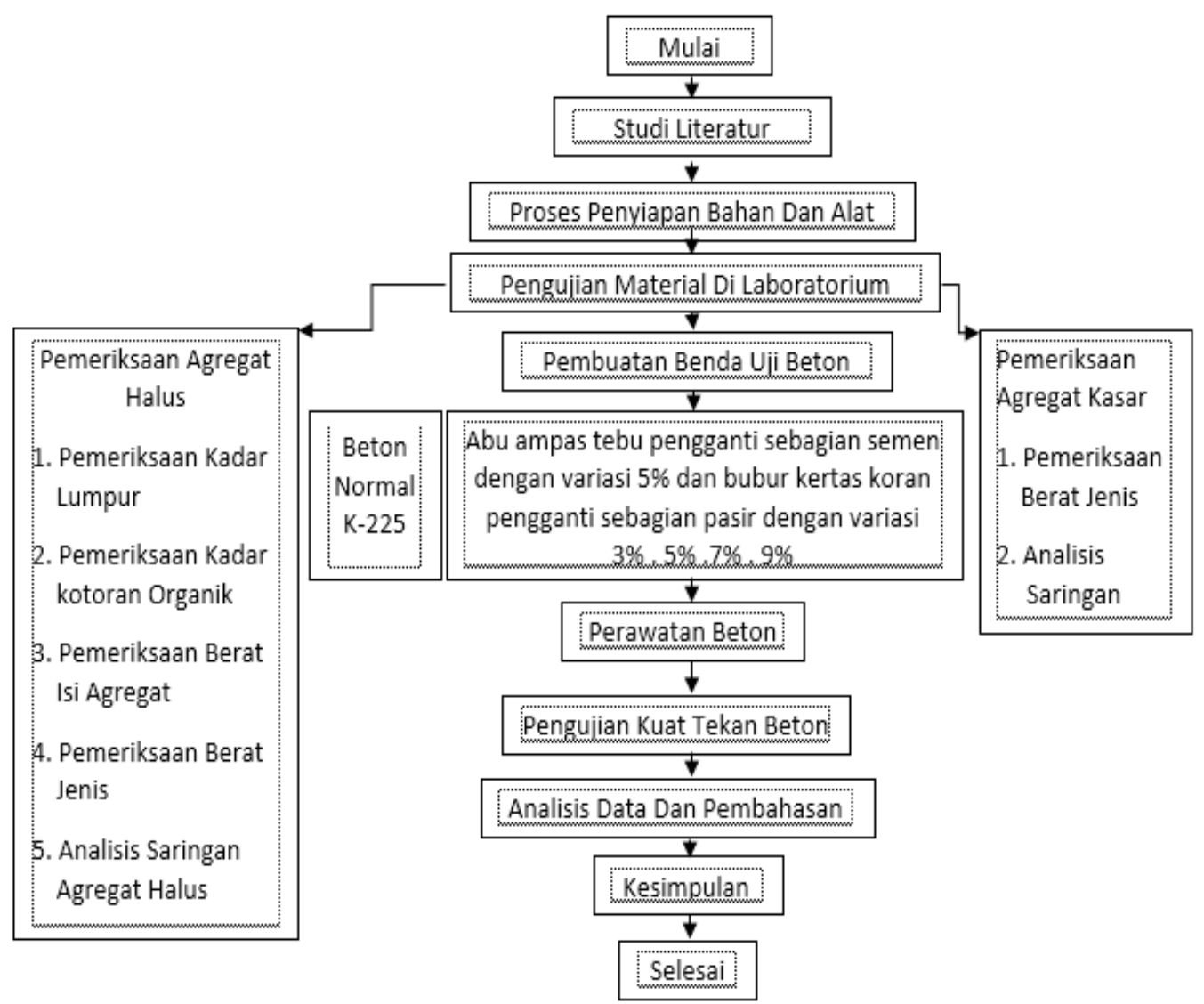

Gambar 1. Bagan alir pengaruh penambahan abu ampas tebu dan bubur kertas koran terhadap kuat tekan beton mutu K-225

\subsection{Bahan}

Bahan-bahan yang digunakan dalam penelitian adalah sebagai berikut:

1. Semen Portland Tipe I yang digunakan semen Baturaja.

2. Agregat halus, pasir yang digunakan dari Tanjung Raja.

3. Agregat kasar, split atau batu yang digunakan dari Merak.

4. Air yang digunakan adalah air sumur bor di laboratorium PT. Graha Tekindo Utama Palembang.

5. Abu ampas tebu yang digunakan berasal dari pedagang es tebu di Palembang.

6. Bubur kertas koran, koran yang digunakan Sriwijaya Post, Sumatera Ekspres.

\subsection{Peralatan}

Peralatan yang digunakan dalam penelitian adalah sebagai berikut:

1. Cetakan beton yang berbentuk kubus ukuran $15 \mathrm{~cm} \times 15 \mathrm{~cm} \times 15 \mathrm{~cm}$.

2. Mesin uji kuat tekan.

3. Ember.

4. Baskom.

5. Timbangan yang digunakan untuk menimbang bahan penyusun beton.

6. Sekop semen.

7. Ayakan 1 set.

8. Mesin molen listrik.

9. Sendok cekung.

10. Gelas ukur. 
Peralatan pengukur slump test yaitu sebagai berikut:

1. Kerucut dengan diameter di bagian bawah $20 \mathrm{~cm}$, bagian atas $10 \mathrm{~cm}$, dan tinggi $30 \mathrm{~cm}$.

2. Tongkat besi pemadat slump.

3. Plat atau papan dengan permukaan rata.

4. Sendok spaci.

5. Meteran.

\subsection{Sampel Uji Laboratorium}

Penelitian ini dilakukan dengan sampel beton K-225 dibuat sebanyak 12 benda uji yang akan diteliti kuat pada umur 28 hari dimana setiap variasinya dibuat 3 sampel. Benda uji coba berbentuk kubus yaitu dengan ukuran $(15 \mathrm{~cm} \times 15 \mathrm{~cm} \times 15 \mathrm{~cm})=3.375 \mathrm{~cm}$.

\subsection{Pengujian Slump Beton}

Uji slump ini dilakukan dengan cara sebagai berikut:

1. Masukkan adukan beton kedalam cetakan yang berbentuk kerucut terpancung dengan ukuran standar diameter puncak $10 \mathrm{~cm}$, diameter dasar $20 \mathrm{~cm}$ dan tinggi $30 \mathrm{~cm}$, dalam 3 lapisan. Lapisan pertama dituangkan sebanyak 1/3 dari dasar kerucut, lapisan kedua dituangkan kembali sebanyak 2/3 dari dasar kerucut, dari lapisan, dan lapisan terakhir dituangkan adukan beton tersebut sampai penuh. Pada setiap lapisannya dipadatkan dengan cara ditumbuk dengan menggunakan tongkat pemadat.

2. Ratakan permukaan beton dan biarkan selama 30 detik.

3. Angkat cetakan perlahan-lahan dengan posisi pengangakatan cetakan harus benar-benar vertikal.

4. Ukur penurunan slump yang terjadi dimana penurunan ini diukur dengan kerucut sebagai acuan pengukurannya. Pengukuran ini dilakukan pada 31 titik yaitu pada permukaan tinggi, dilakukan pada 30 titik yaitu pada permukaan yang paling tinggi, sedang dan rendah. Kemudian ambil rata-rata dari ketiga titik tersebut.

5. Dalam penelitian ini diguakan ukuran slump 60-80 mm.

\subsection{Pembuatan Benda Uji Sampel}

Langkah-langkah pembuatan benda uji sampel antara lain:

1. Alat yang akan digunakan dibersikan terlebih dahulu, kemudian menimbang bahan-bahan yang akan digunakan.

2. Menyiapkan molen yang bagian dalamnya sudah dilembabkan. Pertama tuangkan agregat halus, agregat kasar, semen, dan abu ampas tebu, aduk sampai merata bahan tersebut.

3. Setelah bahan tercampur masukan air dikit demi sedikit.

4. Setelah semua tercampur rata, tuangkan adukan ke dalam cetakan beton.

5. Sampel yang sudah dicetak didiamkan selama 24 jam.

6. Setelah 24 jam cetakan dibuka.

\subsection{Perawatan Beton (Curing)}

Perawatan dengan cara perendaman benda uji atau sempel mulai dari 24 jam sampai waktu yang ditentukan. Perendaman ini berjutuan untuk mengetahui perbedaan variasi lama perendaman terhadap kuat benda uji beton setelah umur 28 hari.

\subsection{Pengujian Kuat Tekan Beton}

Uji kuat tekan beton ini dilaksanakan setelah usia beton mencapai 28 hari, berikut langkahlangkah dari uji kuat tekan beton ialah sebagai berikut: 
1. Beton yang direndam dan telah cukup umur untuk uji kuat tekan beton diambil dari tempat perenadamannnya.

2. Keringkan beton yang akan diuji dengan menggunakan lap kering kemudian lakukan pengukuran berat.

3. Timbang benda uji.

4. Letakan beton yang akan diuji ke dalam mesin hammer test setelah itu tekan benda uji tersebut, besar beban yang didapat tertera di mesin kuat tekan.

5. Beton yang akan diuji diperiksa kuat tekannya berdasarkan PBI 1991 berbentuk kubus dengan spesifikasi.

\subsection{Analisis Data}

Data yang diperoleh dari hasil pengujian kuat tekan beton di laboratorium kemudian dianalisis dan diolah untuk mendapatkan kuat tekan beton karakteristik. Persamaan 1 berikut yang digunakan untuk mendapakan nilai deviasi.

$$
S=\sqrt{\frac{\sum_{1}^{n}\left(\sigma_{b i}-\sigma_{b m}\right)^{2}}{n-1}}
$$

keterangan:

$S \quad=$ deviasi standar $\left[\mathrm{kg} / \mathrm{cm}^{2}\right]$,

$\sigma_{b i} \quad=$ kuat tekan beton yang didapat dari masing-masing benda uji $\left[\mathrm{kg} / \mathrm{cm}^{2}\right]$,

$\sigma_{b m} \quad=$ kuat tekan beton rata-rata $\left[\mathrm{kg} / \mathrm{cm}^{2}\right]$,

$n \quad=$ jumlah seluruh nilai hasil pemeriksaan, jadi jumlah seluruh benda uji yang diperiksa.

\subsection{Hasil Uji Kuat Tekan}

Dari hasil pengolahan data yang telah dijabarkan di atas, serta pada Tabel 1 dan Gambar 2 di bawah. Maka dapat ditarik beberapa hasil rangkuman mengenai kuat tekan karakteristik beton pada penelitian ini diantaranya sebagai berikut.

1. Pada variasi campuran terjadi penurunan kuat tekan beton dari beton normal.

2. Semakin banyak persentase campuran pada beton maka hasil pengujian kuat tekan beton semakin menurun.

3. Dari hasil uji kuat tekan untuk penambahan abu ampas tebu dan bubur kertas koran, mengalami penurunan kuat tekan pada saat umur 28 hari lebih kecil dari pada campuran beton normal $\mathrm{K}-225$, masing-masing penambahan kuat tekan beton dengan penambahan abu ampas tebu dan bubur kertas koran hasil yang didapat yaitu AAT $5 \%+$ BK 3\% $=\mathrm{K}-$ 200, AAT $5 \%+$ BK $5 \%=K-175$, AAT $5 \%+$ BK $7 \%=K-137$, AAT $5 \%+$ BK $9 \%=K-$ 113.

Tabel 1. Hasil Uji Kuat Tekan

\begin{tabular}{cccc}
\hline No. & Sampel & $\begin{array}{c}\text { Umur Sampel } \\
{[\text { hari] }}\end{array}$ & $\begin{array}{c}\text { Kuat Tekan Beton Rata-rata } \\
{\left[\mathbf{k g} / \mathbf{c m}^{\mathbf{2}}\right]}\end{array}$ \\
\hline 1 & Beton Normal & 28 & 230,44 \\
\hline 2 & BN + AAT 5\% + BK 3\% & 28 & 200,22 \\
\hline 3 & BN + AAT 5\% + BK 5\% & 28 & 175,29 \\
\hline 4 & BN + AAT 5\% + BK 7\% & 28 & 137,51 \\
\hline 5 & BN + AAT 5\% + BK 9\% & 28 & 113,33 \\
\hline
\end{tabular}




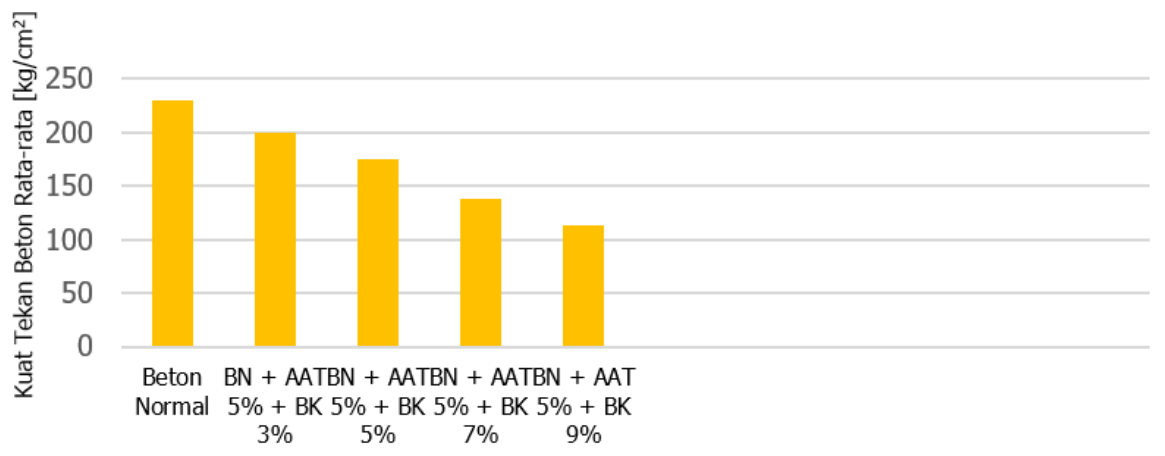

Gambar 2. Nilai kuat tekan beton rata-rata

\section{KESIMPULAN}

Dari penelitian yang dilakukan di laboratorium didapat beberapa kesimpulan sebagai berikut:

1. Dari hasil uji pembakaran ampas tebu pada temperatur $230^{\circ} \mathrm{C}$ didapatkan kandungan silika sebesar $58,35 \%$.

2. Dari hasil pengujian untuk penambahan abu ampas tebu dan bubur kertas koran pada campuran beton mengalami penurunan kuat tekan pada saat umur 28 hari lebih kecil dari pada campuran beton normal K-225, hasil dari penambahan abu ampas tebu dan bubur kertas koran didapatkan nilai kuat tekan beton antara lain AAT 5\% + BK 3\% $=\mathrm{K}-200, \mathrm{AAT} 5 \%+\mathrm{BK} 5 \%=\mathrm{K}-175$, AAT $5 \%+\mathrm{BK} 7 \%=\mathrm{K}-137, \mathrm{AAT} 5 \%+\mathrm{BK} 9 \%=$ $\mathrm{K}-113$.

3. Semakin banyak penambahan abu ampas tebu dan bubur kertas koran pada adukan beton semakin rendah nilai kuat kuat tekan beton.

4. Semakin banyak kadar abu ampas tebu dan bubur kertas koran yang digunakan pada campuran beton membuat warna benda uji berwarna kehitaman dan berat benda uji menjadi semakin menurun.

\section{DAFTAR PUSTAKA}

Adiguna, A. \& Wahyudi, A. (2020). Pemanfaatan Abu Ampas Tebu Limbah Pabrik Gula Cinta Manis Kabupaten Ogan Ilir Sebagai Additive Beton. Sainmatika: Jurnal IImiah Matematika dan IImu Pengetahuan ALam, 17(1), 46-54.

Ahmad, I.A., Pertiwi, N. \& Taufieq, N.A.S. (2017). Sifat Workability Beton Ramah Lingkungan. Seminar Nasional LP2M UNM (pp. _-_ ). Makassar: LP2M UNM.

Departemen Pekerjaan Umum. (1989). Spesifikasi Bahan Bangunan Bagian A (Bahan Bangunan Bukan Logam). Jakarta: Departemen Pekerjaan Umum.

Gardjito, E., Candra, A.J. \& Cahyo, Y. (2018). Pengaruh Penambahan Batu Karang Sebagai Substitusi Agregat Halus Dalam Pembuatan Paving Block. UKaRsT (Universitas Kadiri Riset Teknik Sipi), 2(1), 38-46.

Hidayat, S. (2009). Semen: Jenis \& Aplikasinya. Jakarta: Kawan Pustaka.

Ikhsan, M.N., Prayuda, H. \& Saleh, F. (2017). Pengaruh Penampangan Pecahan Kaca Sebagai Pengganti Agregat Halus dan Penambahan Fiber Optik terhadap Kuat Teka Beton Serat. Semesta Teknika, 19(2), 148-156.

Katrina, G. (2014). Pemanfaatan Limbah Kulit Kerang Sebagai Substitusi Pasir dan Abu Ampas Tebu Sebagai Subtitusi Semen pada Campuran Beton Mutu K-225. Jurnal Teknik Sipil dan Lingkungan, 2(3), 308-313. 
Lianasari, A.E. \& Paiding, S.D. (2013). Penggunaan Limbah Bubur Kertas dan Fly Ash pada Batako. KoNTekS (Konferensi Nasional Teknik Sipil) 7 (pp. ____). Surakarta: Universitas Sebelas Maret.

Pane, F.P., Tanudjaja, H. \& WIndah, R.S. (2015). Pengujian Kuat Tarik Lentur Beton dengan Variasi Kuat Tekan Beton. Jurnal Sipil Statik, 3(5), 313-321.

Permatasari, S. (2019). Pengaruh Bahan Tambah Batu Bata Merah terhadap Kuat Tekan Beton fc' 21 Menggunakan Agregat Kasar PT. AMR dan Agregat Halus Desa Sunggup Kota Baru. Tapak (Teknologi Aplikasi Konstruksi): Jurnal Program Studi Teknik Sipil, 8(2), 155-161.

Rajagukguk, S.A. (2017). engaruh Abu Ampas Tebu Sebagai Bahan Tambah Semen Terhadap Sifat - Sifat Mekanik Beton dengan Menggunakan Pasir Siantar. Tugas Akhir. Medan: Universitas Sumatera Utara.

Riski, A. \& Farlin, R. (2019). Analisis Perbandingan Jenis Semen (Merk Semen) terhadap Kuat Tekan Beton. Doctoral Disertation. Palembang: Universitas Bina Darma.

Rusyandi, K., Mukodas, J. \& Windah, R.S. (2012). Perancangan Beton Self Compacting Concrete (Beton Memadat Sendiri) dengan Penambahan Fly Ash dan Structuro. Jurnal Konstruksi - STT Garut, 10(1), 1-11.

Yulianti, A. (2015). Prototype Alat Pengolahan Air Laut Menjadi Air Minum (Pengaruh Variasi Packing Filter terhadap Kualitas Air dengan Analisis DO, Salinitas dan Konduktivitas). Doctoral Dissertation. Palembang: Politeknik Negeri Sriwijaya. 